\section{O princípio da dignidade humana à luz da bioética}

\section{Bonhemberger, Marcelo}

Doutor em Filosofia. Professor da Escola de Humanidades da PUCRS.Marcelo.bonhemberger@pucrs.br

Crippa, Anelise

Doutora em Gerontologia Biomédica. Professora Universitária.Advogada.advcrippa@hotmail.com.

PALAVRAS-CHAVE: Dignidade; pluralidade;

O presente texto tem como objetivo refletir sobre a dignidade da pessoa humana, princípio fundante da Declaração Universal dos Direitos Humanos. Trata-se de uma revisão bibliográfica a partir da conceituação e análise de referenciais teóricos. Embora nos últimos anos, sobretudo com o avanço das ciências da vida, da biotecnologia e da bioética, o termo vem questionado como sendo impreciso e, na interpretação de alguns autores, considerado como "inútil". Numa perspectiva histórica, a sociedade sempre se preocupou com a dignidade humana, mas paradoxalmente, no século XXI, o ser humano continua sendo agredido em sua dignidade. Se de um lado, há agressão à dignidade, de outro, crescem o sentimento e os esforços em sua defesa. Sob o ponto de vista jurídico, com o fim da Segunda Guerra Mundial, houve uma tomada de consciência universal, tendo como base uma razão declarativa de conteúdo ético, fundada na garantia da intangibilidade da dignidade da pessoa humana. Desse modo, observa-se que o princípio de dignidade pressupõe questões de eticidade e normatividade as quais apontam para uma forma de tratar e julgar as pessoas de acordo com suas ações voluntárias e não segundo outras propriedades e circunstâncias, o que permite concluir que qualquer pessoa humana, independentemente de sua condição particular, possui valor intrínseco, porquanto inerente ao processo civilizatório. $\mathrm{O}$ horizonte polissêmico da ideia de dignidade humana e sua aplicação conduzem à dificuldades acerca de questões bioéticas.

\section{REFERÊNCIAS}

[1] ASHCROFT, Richard. Making sense of dignity. Journal of Medical Ethics, v. 31, p. 679-82, 2005.

[2] BAERTSCHI, Bernard. Ensaio filosófico sobre a dignidade: antropología e ética das biotecnologías. São Paulo: Loyola, 2009.

[3] CASADO, María (org.). Sobre a dignidade e os princípios: análise da declaração universal sobre bioética e direitos humanos da Unesco. Janaína de Azevedo Baladão (trad.). Porto Alegre: EDIPUCRS, 2013.
[4] FOSTER, Charles. Human Dignity in Bioethics and Law. Londres: Hart Publishing, 2011.

[5] MACKLIN, Ruth. Dignity is a useless concept. British Medical Journal, v. 327, p. 1.419-20, 2003. 